\title{
Evaluating A Broad Scope of Transboundary Water Sharing Benefits With Hydro-Economic Modelling
}

Mohammad Abul Hossen

University of South Australia

Jeffery D Connor ( $\boldsymbol{\nabla}$ jeff.connor@unisa.edu.au )

University of South Australia https://orcid.org/0000-0002-2313-8630

Faisal Ahammed

University of South Australia

Research Article

Keywords:

Posted Date: January 17th, 2022

DOI: https://doi.org/10.21203/rs.3.rs-1029719/v1

License: (c) (1) This work is licensed under a Creative Commons Attribution 4.0 International License.

Read Full License 


\title{
Evaluating a Broad Scope of Transboundary Water Sharing Benefits with Hydro-economic Modelling
}

\author{
Mohammad Abul Hossen, Jeffery D Connor and Faisal Ahammed
}

\begin{abstract}
There are more than 260 transboundary river basins in the world which cover nearly half of the Earth's surface. These rivers, traversing around 145 countries, are a common cause of conflict between nations. The case study selected for this study is the Teesta River, a tributary to the Brahmaputra which flows from India to Bangladesh, where water sharing between India and Bangladesh has a long and disputed history. The model quantifies economic net benefit of opportunities to share water between the countries using a HydroEconomic Model (HEM).

Whilst HEMs exist for many transboundary river basins including the Nile Basin, the Ganges Basin, the Mekong, Volta, and Amu Darya, most HEMs that treat transboundary water issues consider a limited scope of water values most frequently including: agriculture, hydropower, and municipal water uses. However, water has many additional values including navigation, environment, fisheries, and water quality. This study adds to the HEM literature by considering a wider range of benefits than have commonly been included in HEM assessments of transboundary water sharing in the past. Results show that a re-allocation scenario with more water flowing over the border from India to Bangladesh leads to an overall annual basin-wide gain. The estimated loss for India (mostly lost hydropower value) would be substantially greater if non-extractive flow related benefits for fisheries, navigation, sediment transport and environment were not accounted for. Similarly, estimated gain for Bangladesh would be much less if these nonextractive flow related benefits were ignored.
\end{abstract}




\section{Author Declarations}

-Ethical Approval - No ethics approvals were required as no human subjects or animal experiments were involved.

-Consent to Participate were not required

-Consent to Publish is granted through University of South Australia

-Authors Contributions: Mohammad Hossen - analysis and writing, Jeff Connor - writing, Ahmad Faisal - writing.

-Funding - Bangladesh Scholarship Council supported the PhD scholarship which produced this research

-Competing Interests - There are no competing interests

-Availability of data and materials - All data is available in the University of South Australia thesis that are the basis of the article 


\section{Evaluating a Broad Scope of Transboundary Water Sharing Benefits with Hydro-economic Modelling}

\section{Introduction}

There are more than 260 transboundary river basins and 450 aquifers which cover nearly half of the Earth's surface (Eckstein \& Sindico 2014; Sadoff \& Grey 2005). These river basins traverse 145 countries that are home to 40 percent of the world's population (Abseno 2013; Grey \& Sadoff 2003; Mianabadi et al. 2015). History tells us that conflict over water in these basins is less often caused by scarcity of water than by poor governance or management of water (Rai et al. 2017). Literature also suggests that the water storage or diversion of water in the upstream, which causes variability of flow (high or low), or scarcity of water in the downstream, are common sources of transboundary water disputes (Yorth 2014). Good water governance such as good policy, high quality river basin organizations, stakeholders participation, transparency, accountability, and rules of law can of mitigate transboundary water disputes (Ogren 2015; Stefano et al. 2014).

A first step in any improvement in transboundary water governance and water sharing is to develop information about the potential implications of different water management and sharing arrangements. Hydro-economic models (HEMs) that simulate flows, water uses and economic values of uses play an increasing role in elucidating the possibilities to deal with water scarcity, drought, and climate change, and test the effects of infrastructure and policy responses to cope with water management problems (Kahil, Dinar \& Albiac 2015). Such models integrate hydrologic, economic, institutional, and environmental variables, and involve water values relevant to stakeholders in a basin (Habteyes et al. 2015).

Different types of Hydro-economic models (HEMs) have been applied to transboundary water sharing issues in different river basins with structure depending on catchment biophysical characteristics, major water demands, infrastructure, and policy context differences (Bekchanov, M et al. 2017; Momblanch et al. 2016). Many HEMs have been applied to transboundary water sharing issues including for the Nile Basin, the Ganges basin, the Mekong, the Zambezi, the Koshi, the Indus, the Volta and the Amu Darya basins (Amjath-Babu et al. 2019; Basheer et al. 2018; Digna et al. 2017; Gonzalez et al. 2021; Jalilov 2021; Vinca et al. 2021; Wu et al. 2013) 
The studies that apply HEMS to transboundary water sharing generally find significant net basin benefit from alternatives to current water sharing. For example, on the Zambezi, the estimated average annual cost of non-cooperation is 350 million USD, which is $10 \%$ of the total annual water benefit (Tilmant \& Kinzelbach 2012). For the Nile, one estimate of potential annual economic benefits from cooperative water management is USD 7-11 billion (Whittington, Wu \& Sadoff 2005). Also for the Nile, Habteyes et al. (2015) showed that Ethiopia can gain USD 2.6 billion benefit with no other country worse off from a better managed operation of Ethiopian and Egyptian dams. Similarly, it is estimated that Ethiopia's economic benefits can be increased 5-6 times without significant harm to downstream countries if Grand Ethiopian Resonance Dam (GERD) can be operated with full cooperation (Jeuland, Wu \& Whittington 2017).

HEM models applied to transboundary water issues have developed over time. One development has been the inclusion of broader economy follow-on impacts assessment with computable equilibrium modelling (Eamen, Brouwer \& Razavi 2021). Other recent developments have been better representation of more and less cooperation in co-riparian countries' water management (Basheer et al. 2018; Gonzalez et al. 2021), and evaluations of transboundary water management strategy resilience to climate change (Amjath-Babu et al. 2019). The evolution that we focus on in this article is the scope of benefits accounted for, which has evolved over time to be more inclusive. In example, first applications of the Nile Economic Optimization Model, developed by Whittington, Wu and Sadoff (2005), were typical for the era in that they determined the pattern of water use that would maximize benefits from agriculture and hydropower. Other researchers extended its application to also include municipal and industrial use and the economic effects for different combinations of hydraulic structures and stakeholders (Basheer \& Elagib 2018; Basheer et al. 2018; Strzepek et al. 2008). Some early HEMs, such as the Mekong basin model by Ringler, Braun and Rosegrant (2009), expand on the more commonly covered irrigated agriculture, domestic-industrial, and hydropower to include wetlands, and fisheries. However, most transboundary HEMs still include at most four sectors. In addition to irrigation, municipal industrial and hydropower values, a few HEMs treating transboundary water sharing, consider a broader benefit scope such as fisheries (Do et al. 2020); water for power station cooling (Eamen, Brouwer \& Razavi 2021); water pollution (Kahil, Dinar \& Albiac 2015). The evidence from these models suggests 
that accounting for a wider range of flow dependent non-extractive water values can substantially alter conclusions about optimal water allocation.

The article makes a unique contribution to the HEM literature examining transboundary water sharing benefits by taking account of a larger range of water values than most past similar HEMs. Though various types of benefits are addressed existing HEMs, most only focus on irrigation, and hydropower with less frequent accounting for three or more values, most often either municipal industrial or environmental water (Hossen, Connor \& Faisal 2022). The model applied in this study accounts for irrigation, hydropower and municipal industrial water supply which are extractive water uses. It also accounts for a wider range of non-extractive flow dependent benefits than past HEMs applied to transboundary issues including fisheries, environment, sedimentation, and river transport benefits.

The article is organized as follows: Section 2 describes the Teesta River case study; Section 3 describes the Teesta hydro-economic model used to assess the economic value of water in Bangladesh and India in the baseline and alternative water sharing scenarios evaluated; Section 4 describes the potential gain and loss for India and Bangladesh for a change from current water sharing rules to a proposed alternative agreement; Finally, conclusions are discussed in section 5 .

\section{Teesta Basin case study}

Like many other river basins, there are water sharing disputes among the co-riparians of the Ganges-Brahmaputra-Meghna (GBM) basin, one of the largest river systems in the world. This system encompasses 54 of the 57 transboundary rivers flowing into Bangladesh from India. Among them, more than 25 rivers are affected by upstream water diversions, especially in the dry season (Kawser \& Samad 2016). One tributary to the GBM, the Teesta River, Bangladesh's fourth largest river, is the focus of this study. The Indian Government started constructing the Teesta Barrage Project (TBP) at Gajaldoba, Jalpaiguri district of West Bengal province, $80 \mathrm{~km}$ upstream of the India-Bangladesh border in 1976, aiming to irrigate of 922,000 hectares (ha) of land and generate 67.5 Mega Watts (MW) of hydropower (Department of Irrigation and waterways 2017). The Bangladesh Government started the Teesta Barrage Irrigation Project (TBIP) on the Teesta at Dalia, $20 \mathrm{~km}$ south of the India-Bangladesh border in 1979 intending to irrigate 750,000 ha of land (Figure Error! No text of specified style in document.: ). 


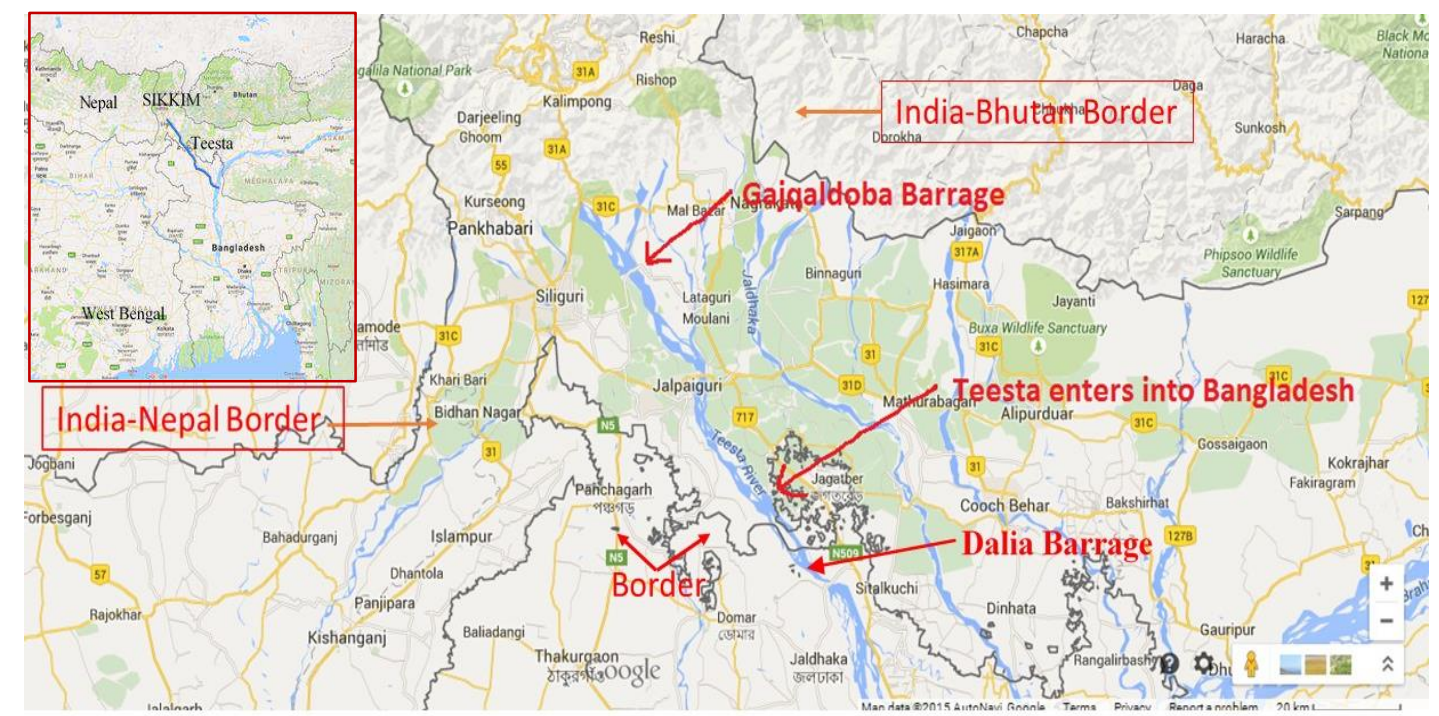

Figure Error! No text of specified style in document.: Location of Teesta Barrage (Source Google)

When India started operation of the TBP, the dry season flow in Bangladesh decreased by $88 \%$, which adversely impacted fisheries, agriculture, navigation, vegetation, and increasing siltation due to low flow in the dry season which causes the river overflow flood damage (Afroz \& Rahman 2013; Haque et al. 2014; Mullick, Md. Reaz Akter, Perret \& Babel 2014; The Asia Foundation). Over the years multiple proposals to share the basin's transboundary flow differently have been proposed. This includes a 1983 IndoBangla Joint River Commission (JRC) proposal to allocate 39\% of dry season flow for India, 36\% for Bangladesh, and 25\% for environmental flow (Adhikary et al. 2000). A later (2010) water-sharing proposal was for 50-50 India, Bangladesh flow sharing after keeping 20\% for environmental flow (Bagchi 2011). Yet, the Teesta dispute is still unresolved despite ongoing negotiation between the countries (Bagchi 2011; Sarkar 2017).

\section{Teesta Hydro-Economic Model}

The HEM prepared for this study considers the distinct features of the Teesta River basin. As the water sharing dispute is only in the dry season due to scarcity of water, the model operates for the dry season, November to April (six months of a year). It operates on 10 day time steps, as river inflow/diversion data is available on a 10 day basis. The model was coded in GAMS and solved using the CONOPT 3 solver which is a non-linear, optimization model. 
Two scenarios are modelled.

Scenario 1 (Baseline): Data from 2008-09 was used to represent Basin baseline conditions because the average flow (4074cusec) for that year is close to average flow (4143 cusec) of the years for which records exist (2005-2010), and because the amount of water released from Gajaldoba barrage, just above the Bangladesh, India border, in that year ( 1410 cusec) is also similar to the average for all years with record data ( 1559 cusec). This choice of baseline year is also consistent with use of flow benefit with equations for fisheries and navigation benefits based on a primary survey carried out in the basin in 2009 (Mullick, Md Reaz Akter, Babel \& Perret 2011). Moreover, many key economic parameter values required for the study were only available for 2009. The baseline model represents how India has diverted water from immediately upstream since 2000 and has reduced flow immediately downstream of the barrage to $30 \%$ of pre-diversion levels.

Scenario 2 (Water Sharing): The second scenario is water sharing according to a proposal for India and Bangladesh to each divert $40 \%$ water of Teesta flow, leaving $20 \%$ for of flow in stream below Dalia barrage (Bagchi 2011).

\section{Teesta River Basin Schematic}

Only part of the Teesta is included in this model, the area starting from Gajaldoba barrage and ending at Sundarganj/Chilmari, the outfall of the river at Brahmaputra, about $200 \mathrm{~km}$ further downstream. The modelled inflows, and outflows are represented in the Teesta River Basin Schematic (TRBS) as a network of nodes and links where nodes represent the river reaches and extractions, and links represent the linkage between these objects (Ringler, Braun \& Rosegrant 2009; Whittington, Wu \& Sadoff 2005). There are five basic types of nodes: river reaches, reservoirs, irrigation withdrawals, and inflows from tributaries (Jalilov, Varis \& Keskinen 2015). Inflows represented are from the main river, three groundwater inflows, water diversions represented are from two river nodes to two big irrigation projects, one municipal diversion, and one hydropower production station which is on the diversion canal (Figure 2). From the first node, water can be diverted to both right and left canal of the barrage. Water from the left diversion can only be used for irrigation while the right diversion can be used for irrigation, municipal water supply, hydropower and then irrigation again. 


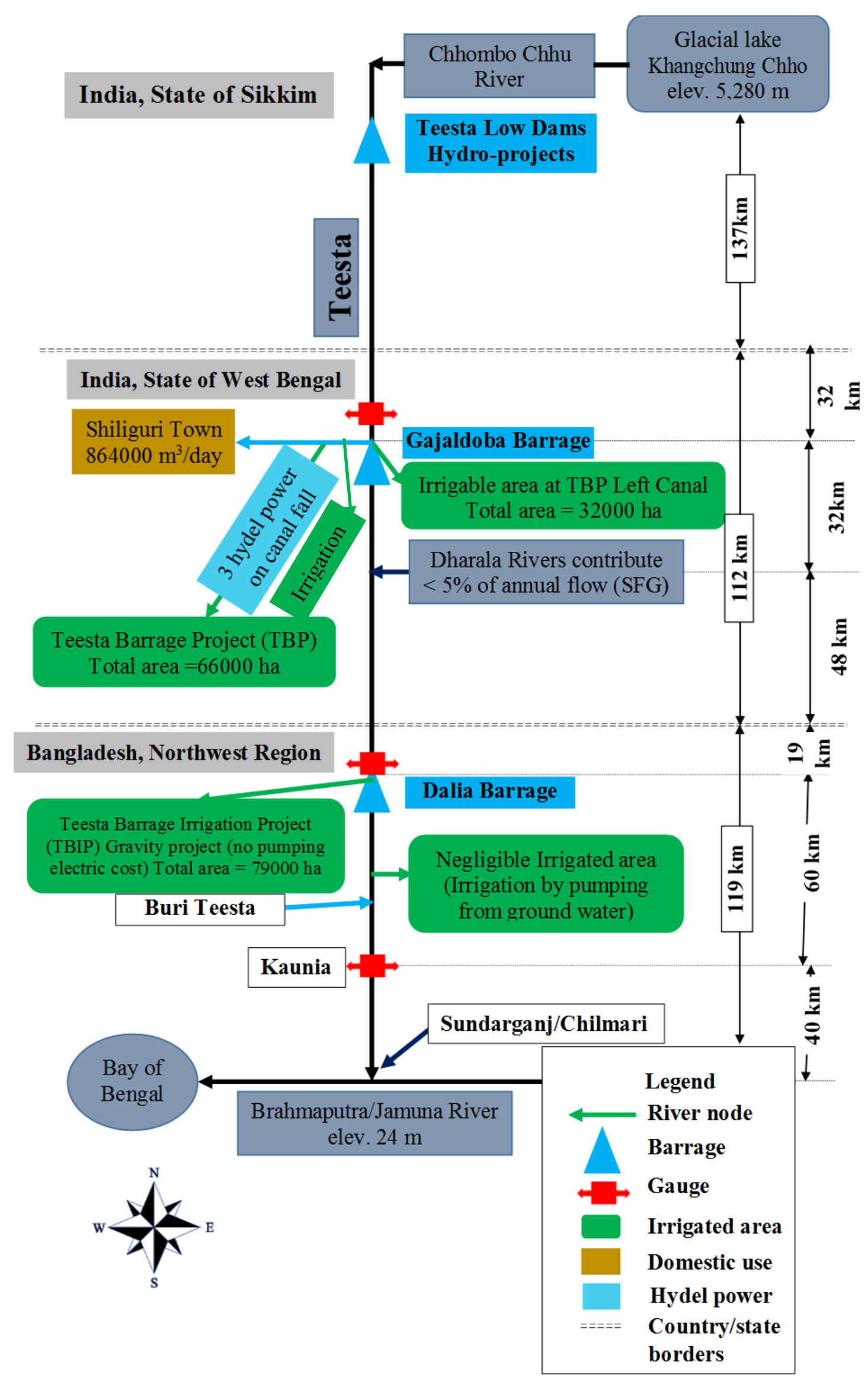

Figure 2: Simplified Network of the Teesta River System 
Although there are some smaller diversions between Dalia and Kaunia by low lift pumps for irrigation or domestic use, they are negligible. The hydroelectric projects situated upstream of the river are shown as a single point. There are many tributaries upstream of Gajaldoba barrage which are not included as our focus is from Gajaldoba to Sundarganj/Chillmari. Two tributaries are included: the Dharala, which meets the Teesta at Domohoni, 32km downstream of Gajaldoba barrage; and the Buri Teesta $15 \mathrm{~km}$ downstream of Dalia barrage.

\section{Model Objective}

The model is a hybrid optimization and simulation. The objective is to optimize total economic benefits from agriculture, hydropower and municipal uses for the whole river basin (Equation 1). The other benefits: fisheries, navigation, environmental and sediment transport, are benefits of instream flow. They were not included in the objective function. Rather, the model assessed how the levels of these benefits change when more water is released to Bangladesh from India.

$\operatorname{Max} \mathrm{Z}=\sum_{i, j, t}$ BEN_Ag $i, j, \mathrm{t}$

Where,

$B E N \_A g_{i, j, t}$ is the agricultural benefits at country $\mathrm{i}$, crop $\mathrm{j}$ and time $\mathrm{t}$;

$B E N_{-}$Hydro $_{t, l}$ is the hydropower benefits at time t and location 1;

$B E N_{-} M_{t, l}$ is the municipal benefits for the same subscript.

Many constraints consistent with current and potential future water sharing rules were also included in the model. For example, in the baseline scenario, the model can divert a maximum of $70 \%$ of water within India above the Bangladesh border consistent with current diversion levels. In the water-sharing scenario, a maximum of $40 \%$ of in-flow at Gajaldoba barrage can be diverted in India, a maximum of $40 \%$ of flow can be diverted below the border in Bangladesh, and a minimum of $20 \%$ of flow is reserved for river flow below Dalia Barrage. Moreover, municipal diversion is the highest priority in both scenarios.

\section{Water balance components}

The major components of the water balance represented are: 
A. Inflows included are from of the Gajaldoba barrage immediately upstream of the Bangladesh, India border; groundwater flow to the river and flow from two small tributaries the Dharala and the Buri Teesta. As our focus is the dry season only, the inflow from surface runoff due to precipitation/ rainwater can be considered as zero.

B. Outflows are included for a canal on the Indian side of the border where water is diverted for irrigation, hydropower and domestic use in Shiliguri town and from conveyance losses. The only outflow on the Bangladesh side included is diversion from Dalia barrage which is used for irrigation by the TBIP.

C. Return flows are included for the part of diversion for irrigation from the river in India that passes to groundwater through seepage and back into the Teesta through groundwater inflow. Other than this, return flow from agriculture to the river is insignificant due to the topography of the basin.

D. Off-stream uses accounted for include water diverted on the Indian side of the border for irrigation, and domestic purpose at Shiliguri town. The remaining water is carried to Mahananda main canal to produce instream hydropower at three locations. Additional water is diverted in Bangladesh for the Teesta Barrage Irrigation Project (TBIP), which is completely used for irrigation.

E. In-stream uses accounted for include the water released after diversion in India which is available for navigation and fisheries downstream. The amount of water released from Dalia barrage is available for navigation and fisheries from Dalia to Kaunia. The water released downstream from Kaunia is available for navigation and fisheries from Kaunia to Sundarganj. The flow that meets the Brahmaputra at Sundarganj contributes the ecosystem services of the Brahmaputra, the Padma, and the Meghna River.

Functionally the water balance is represented in the standard form for HEMs.

$$
\text { Inflow }_{t, 1}=\left[\text { OUTflow }_{t,(1-1)}+\text { GWflow }_{t, 1}\right]
$$

Where,

Inflow $w_{t, l}$ - Inflow from upstream of any node in $\mathrm{m}^{3} / \mathrm{sec}$ in time $\mathrm{t}$ and location 1 , OUT flow $_{t,(l-1)}$ - Outflow from a previous node or barrage in $\mathrm{m}^{3} / \mathrm{sec}$, GWflow t $_{t l}$ - Total groundwater flow to the reach (measured at the end node) in $\mathrm{m}^{3} / \mathrm{sec}$,

$$
\text { OUTflow }_{t, l}=\left[\text { Inflow }_{t, l}-\text { TDivert }_{t, l}\right]
$$


Total water diversion at any location has been written as

TDivert $_{t, 1}=\frac{\sum_{j} \text { TWD_Cr }_{i, j, t}}{\text { Conversion Factor }}+$ Hydro_divert $t_{t, I}+$ WDem_m $_{t, 1}$

Where,

OUT flow $_{t, l}$ - Outflow from a node or barrage in $\mathrm{m}^{3} / \mathrm{sec}$,

TDivert $t_{t, l}$ - Total water diverted from a node in $\mathrm{m}^{3} / \mathrm{sec}$

$\sum_{\mathrm{j}} \mathrm{TWD}_{-} \mathrm{Cr}_{\mathrm{i}, \mathrm{j}, \mathrm{t}}-$ Sum of Total water divert for all Crops. It has been divided by Conversion Factor, time (10daysx24hoursX3600seconds) to convert to cumec.

Hydro_divert $_{t, l}-$ Diversion for hydropower

WDem_ $m_{t, l}-$ Total Demand for Municipal use (For this model Shiliguri town)

Total water demand for a crops depends on field water requirements for that crop and quantity of land cultivated for that crop. Total water demand for a crop was calculated as

TWDC $_{\mathrm{i}, \mathrm{j}, \mathrm{t}}=$ WDem $_{\mathrm{cri}}, \mathbf{j}, *$ Convey_loss_ $\mathbf{f}_{j} * \operatorname{HECTRES}_{-} \mathrm{V}_{\mathrm{i}, \mathrm{j}, \mathrm{t}}$

Where,

WDem_cri,j,t - Crop water requirements for 10 days in $\mathrm{m}^{3}$

Convey_loss $f_{j}-$ Conveyance loss factor, 2.5 for this model,

HECTRES_ $V_{i, j, t}-$ Land cultivated for crop $\mathrm{j}$, country $\mathrm{i}$, and time $\mathrm{t}$,

\section{Benefits}

Irrigation

To represent irrigation returns, the economics of the five main crops that are irrigated in the dry season was modelled. Crop information used in the modelling included field water requirement (excluding rainfall), yield, production cost (including irrigation surface water charges and pumping costs for groundwater) and crop prices in India and Bangladesh is summarized in Hossen (2021).

Some data for Indian crops such as winter vegetables were not available, so the same data for Bangladeshi crops were used.

Agricultural benefit for each scenario was calculated as the sum of revenue of all crops summed over all irrigated hectares chosen in optimal solution for each country for the whole dry season. Using local data on irrigation production costs, yields and prices documented in the data section, net revenue for each crop per hectare is computed as 
Net_rev_cr $_{\mathbf{i}, \mathrm{j}}=$ Price_cr $_{\mathbf{j}} *$ Yield_cr $_{\mathrm{i}, \mathrm{j}}-$ Cost_cr $_{\mathbf{i}, \mathrm{j}}$

Based on the water demand, yield, production cost, and crop price, the optimization model chooses to cultivate the most profitable crop on all area available to irrigate within water constraints. Specifically, the model chooses Potatoes for both countries to be the most profitable crop. Therefore, constraints requiring the cropping pattern to represent the actually observed baseline crop mix were introduced for all the scenarios. To restrict crop mixes, parameter AlfaC (crop mix ratio from Hossen (2021)) were multiplied by the total land cultivated in each project Cultivable_land ${ }_{i}$ using the following formula

HECTRES_ $V_{i, j, t}=$ AlfaC $_{\mathbf{j}} *$ Cultivable_land ${ }_{i}$

An additional constraint was implemented to ensure that the sum of irrigated land cannot exceed the total irrigable land area available.

$\sum_{(j)}$ HECTRES_V $\mathbf{V}_{\mathbf{i}, \mathrm{j}, \mathrm{t}} \leq$ Cultivable_land $_{i}$

There is a provision to use groundwater for irrigation if the river water is scarce - the model used groundwater when total water demand for irrigation was less than water available in the irrigation canal. First, the model chose river water, next, it selected groundwater if river water was not available and this incurs a pumping cost.

\section{Hydropower benefits}

Hydropower revenue was calculated by multiplying the production with the wholesale price of electricity (Jalilov, Varis \& Keskinen 2015). The existing hydropower installation cost, known as a sunk cost, was not included (Whittington, Wu \& Sadoff 2005). It was assumed that overhead cost is $10 \%$ of total revenue and net revenue was calculated accordingly. Operation and maintenance $(\mathrm{O} \& \mathrm{M})$ cost of hydropower stations ranges from $1 \%$ to $4 \%$. The International renewable energy agency (ARENA) assumes $2.2 \%$ for large hydropower and $2.2 \%$ to $3 \%$ for smaller projects, with a global average of around $2.5 \%$ (Irena 2012). A recent study indicates that average O\&M costs is USD 45/kW/year for large-scale hydropower projects and around USD 52/kW/year for smallscale hydropower plants (De Jager et al. 2011).

There are three hydro-power units fed by Teesta diversion in India. Hydropower production depends on the amount of water diverted with one unit beginning to operate at 60 cusecs of flow that produces $7.5 \mathrm{MWH}$, two operate at $>120$ cumsecs, three at > 
180 cumsecs. This is represented with the variable hydropower production $\left(P R O \_H y d r o_{(t, l)}\right)$ in MW which was estimated by the following formula

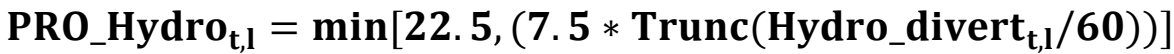

Where

Hydro_divert $t_{t, l}-$ Flow in the diversion canal in cumec

Trunc - GAMS term that convert the decimal value to lower integer

For each MW production, $\mathrm{O} \& \mathrm{M}$ cost for 10 days is USD52*1000/36 which was called Conversion Factor $(\mathrm{CF})$. Thus, the hydro-power benefits $\left(\right.$ Ben_Hydro $\left._{t, l}\right)$ for 10 days is

BEN_Hydro $_{t, 1}=$ Net_rev_hydro $_{t} *$ Pro_Hydro $_{t, i}-$ CF $*$ Pro_Hydro ${ }_{t, i}$

Total Hydropower benefits (T_BEN_Hydro) for six months (November to April) was calculated by summing over the 10 days benefits.

\section{Municipal water benefits}

Municipal water benefits were calculated considering the demand, price of water, and estimated price elasticity of demand (Price_elasticity ${ }_{i}$ ) with the standard consumer surplus model of urban water value (Srinivasan, Gorelick \& Goulder 2010). The price elasticity of demand for developing countries ranges from -0.3 to -0.6 (Nauges \& Whittington 2009). We assumed a median value of -0.45 , which means water is price inelastic as water has few alternatives and is a necessary good.

The slope of elasticity of the consumer demand curve (SLOPE_Elasticity $\left.{ }_{i, t}\right)$ was derived from following formula

SLOPE_Elasticity $_{\mathrm{I}, \mathrm{t}}=$ Price_elasticity $_{\mathrm{i}} * \mathrm{MW}_{-}$price $_{\mathrm{i}, \mathrm{t}} / \mathrm{WDem}_{\mathrm{i}, \mathrm{t}}$

First the intercept, which is the price when quantity demanded is zero, was calculated by the following formula

INTERCEPT $_{i, t}=$ MW_Price $_{i, t}+$ SLOPE_Elasticity $_{i, t} *$ WDem $_{i, t} / M_{-} W_{\text {Price }}, \mathrm{t}$

Then the municipal benefits $\left(B E N_{-} M_{i, t}\right)$ was calculated considering consumers' surplus which is defined as the difference between the total amount that consumers are willing to pay for a good or service and the total amount that they actually do pay (i.e. the market price) using the formula: 
BEN_M $_{\mathrm{i}, \mathrm{t}}=0.5 *\left(\right.$ INTERCEPT $_{\mathrm{i}, \mathrm{t}}-\mathrm{MW}_{-}$price $\left._{\mathrm{i}, \mathrm{t}}\right) * \mathrm{WDem}_{\mathrm{i}, \mathrm{t}}$

Where

$W_{D e m_{i, t}}$ - Municipal water demand.

$M W_{\_}$price $_{i, t}-$ Municipal water price

\section{Fisheries and navigation benefits}

The fisheries and navigation benefits of the Teesta River in 2009 were quantified by Mullick, Md Reaz A, Babel and Perret (2010), who collected information on the variations of income of individual fishermen and boatmen with changes of the river flow within a year, and applied the data to a regression that related flow change to economic return change for the two water flow benefits. The fisheries benefits for this model were calculated as the total change in income for all fishermen for a change in flow predicted with Mullick's regression equation. Similarly, navigation benefits were calculated as the change total income that boatmen earn by carrying goods or passengers predicted for a change in flow with the Mullick, Md Reaz A, Babel and Perret (2010) regression. The authors did not consider any initial cost or operating cost as the marginal cost is only the price of boat or net whereas the operating cost includes labor, time for boating which is run manually. This is justified because the capital costs of fishing and boating are nearly insignificant relative to incomes from these enterprises and the alternative job prospects for the boatmen and fishermen are low paid agriculture laborer wages with very low demand at the best time for fishing and boating.

To calculate total benefits, we use a total benefit quadratic equation for and individual fishermen dependent on flow (Mullick, Md. Reaz Akter, Perret \& Babel 2014). Then aggregated total benefits function by multiplying the individual benefits with the total number of fishermen. The first derivative of the TB function is the marginal benefits function (a linear equation). The total benefits function is nearly linear up to 300 cumec flow. The fisheries benefits are zero when the flow is less than 50 cumec. As dry season flow in the Teesta is below 300cumec, based on his equation, the following linear equation was developed for fisheries benefits $\left(B E N_{-} F_{(t . l)}\right)$ in this model

$$
\mathrm{BEN}_{-} \mathrm{F}_{\mathrm{t} . \mathrm{l}}=\max \left(0, \operatorname{Rev}_{\mathrm{f}(\mathrm{t}, \mathrm{l})} *\left(\operatorname{OUTflow}_{(\mathrm{t}, \mathrm{l})}-50\right)\right)
$$

This is then summed over 10 day time periods $\left(\sum_{1} \mathrm{~T}_{-} B E N_{-} F_{\mathrm{i}}\right)$ and the three stretches where fishing takes place as 
Grand Total Fisheries benefits

$G_{-} T_{-}$BEN_F $=\sum_{1} T_{-} B E N_{-} F_{i}$

Mullick, Md Reaz A, Babel and Perret (2010) also developed similar equations for navigation benefits and quantified the marginal navigation revenue $\left(\operatorname{Rev} v_{t} n_{t, l}\right)$ per 10 days which only occur when flow exceeds a level $\left(\right.$ Minflow $\left._{t, l}\right)$. Thus, navigation benefits $\left(B e n_{-} N_{t . l}\right)$ in this model was calculated by the following equations

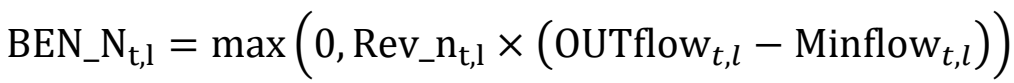

This is summed over 10day intervals and locations to yield Total navigation benefits $\left(T \_B E N_{-} N_{l}\right)$ and over locations to yield $G_{-} T \_B E N \_N$.

G_T_BEN_N $=\sum_{1}$ T_BEN_N

In this study, the model computed the fisheries and navigation benefits from: Gajaldoba to Dalia, Dalia to Kaunia and Kaunia to Sundarganj based on the outflow from these three locations. Benefits were scaled according to the length of the reaches: Gajaldoba to Dalia is $100 \mathrm{~km}$, Dalia to Kaunia is $60 \mathrm{~km}$ and Kaunia to Sundarganj is $40 \mathrm{~km}$.

\section{Environmental benefits}

The benefits due to the augmentation of flow downstream beyond the study boundary was not assessed directly, rather a benefits transfer method using values from a Ganges River study was used (Bekchanov, MB (2014) mentioned in Bekchanov et al 2015). According to a study by Wu et al. (2013), the value of low flows to Bangladesh at the Ganges above the Farakka ranges from $0.00 \mathrm{USD} / \mathrm{m}^{3}$ to $0.10 \mathrm{USD} / \mathrm{m}^{3}$ and the value of water in irrigation ranges from $0.01 \mathrm{USD} / \mathrm{m}^{3}$ to $0.1 \mathrm{USD} / \mathrm{m}^{3}$. The length of the Ganges from Farakka to the Bay of Bengal is around 200km and the length of Brahmaputra to its outfall at the Bay of Bengal is also $200 \mathrm{~km}$ (measured by google distance measure). As the length covered by both the rivers before falling to the sea is equal, the ecosystem benefits produced by the rivers can be assumed to be similar. As a conservative assessment, the value for low flow augmentation has been assumed to $0.01 \mathrm{USD} / \mathrm{m}^{3}$ in this study. This value includes all ecosystem services including fisheries, navigation, salinity prevention and so on. As a whole, these benefits were represented as environment benefits $\left(B E N_{-} E N V_{-} B d_{t, l}\right)$ and calculated by multiplying the value per unit water with the volume of flow per second released from Kaunia and time. 
BEN_ENV_Bd $d_{t, 1}=$ Ben_env $_{\mathrm{t}, \mathrm{l}} *$ Time $*$ OUTflow $_{\mathrm{t}, \mathrm{l}}$

Where,

$B e n_{-} e n v_{t, l}-$ Environment Benefits, for this study $0.01 \mathrm{USD} / \mathrm{m} 3$

OUTflow $_{t, l}$ - Flow that leaves the Teesta basin through Brahmaputra in cumec

Time - Days $*$ Hour $*$ Minute $*$ Seconds

Total environmental benefits $\left(T_{-} B E N_{-} E N V_{-} B d\right.$ ) for six months (November to April) was calculated by summing all the 10 days benefits which can be written as

T_BEN_ENV_Bd $=\sum_{\mathrm{t}, \mathrm{l}}$ BEN_ENV_Bd $\mathrm{t}_{\mathrm{t}, \mathrm{l}}$

Dredging benefits

Dredging benefits were inferred based on a Bangladesh government report: "Feasibility Study of Capital Dredging and Sustainable River Management of Bangladesh (FSCD \& SRMB) (2015)" (BWDB 2015). The study suggested a 15 year dredging plan and provided an estimate of how return to pre-barrage condition dry season flow in the river compared to current (post-barrage flow), would reduce dredging cost. From the same study, a conservative estimate of benefits of self-dredging (auto-dredging) from prebarrage flow is a 10\% reduction from the current USD8.33 million annual dredging cost (BWDB 2015). Dredging benefits calculated on 10 day intervals was assumed to vary linearly with flow changes from current to higher flow conditions $\left(B E N_{-} D r e d g e_{-} B d_{t, l}\right)$ in the ratio of outflow to the inflow relative to baseline case outflow and inflow.

T_BEN_Dredge_BD $=\sum_{\mathrm{t}}$ Ben_Dredge $_{\mathrm{t}, \mathrm{l}} * \frac{\text { outflow }_{t, 1}}{\text { Inflow }_{t, 1}}$

The total annual benefit was calculated by summing over 10 day intervals and dredging benefits in India was assumed to be two-third of dredging benefits in Bangladesh. This is because the length of Teesta in India after Gajaldoba is $80 \mathrm{~km}$, whereas the length of Teesta in Bangladesh is $120 \mathrm{~km}$.

\section{Data}

Hydrological data were collected from the Bangladesh Water Development Board (BWDB), Water Resource Planning Organization (WARPO), Joint River Commission (JRC), and Bangladesh Meteorological Department (BMD). Many data were missing, they were assumed from the average of other year's data. The information on groundwater flow into or from the river were not available directly, we calculated them with 
information about total discharge/flow at a point and release from upstream barrages. In this calculation we assumed groundwater flow to the river between Gajaldoba and Dalia is equal to flow at Dalia minus release/discharge from Gajaldoba barrage. Thus, groundwater flow to the river between Dalia and Kaunia is equal to flow at Kaunia minus release/discharge from Dalia barrage. Some data were in cubic feet/sec (cusec) and some were cubic metre/sec (cumec). All data were converted to cumec.

The retail price of electricity in West Bengal on 01.04.2010 was 5.70 (domestic) and 6.66 (industry) rupees/KWh, we used the average of the two 6.16 rupees/KWh (Open Government Data Platform India 2019). The wholesale price of electricity has been assumed 35\% of retail price (Bulk Energy 2019). Therefore, the wholesale price assumed was 2.156 rupees/KWh which is equivalent to USD37.52/MW. The population of Shiliguri town in 2009 was 513,264 (Shiliguri Subdivision). Assuming 135 liters/day/person consumption, the total water required for 10 days is $692906.4 \mathrm{~m}^{3}$. It was assumed that there is little conveyance loss for supplying water to Shiliguri as water is supplied through the pipe. The installation cost of water supply infrastructure was not included as it is a sunk cost (Bekchanov, M et al. 2015; Whittington, Wu \& Sadoff 2005). Some data for Indian crop (such as winter vegetables) were not available, so the same value for Bangladeshi crops were used. For consistency all other benefit economic values were quantified in the same year (2009). All values were in Bangladeshi Taka or Indian Rupees thus were converted to USD. Complete documentation of all data values, sources and assumptions is publicly available in (Hossen 2021).

\section{Results and Discussion}

\section{Hydrologic Calibration and Validation}

The model was calibrated by trial and error to fit model predictions suitably close to observed values. As 2008-09 flow is near average available time series flow, it was used as a baseline for calibration. The model average amount of water released from Gajaldoba barrage is $26.95 \%$ of water inflow at Gajaldoba which is close to the $30.03 \%$ observed outflow for this year. Model outflow was also compared with observed outflow at three locations. The result is shown in Figure 3 which confirms that model outflow is very close to observed outflow. 


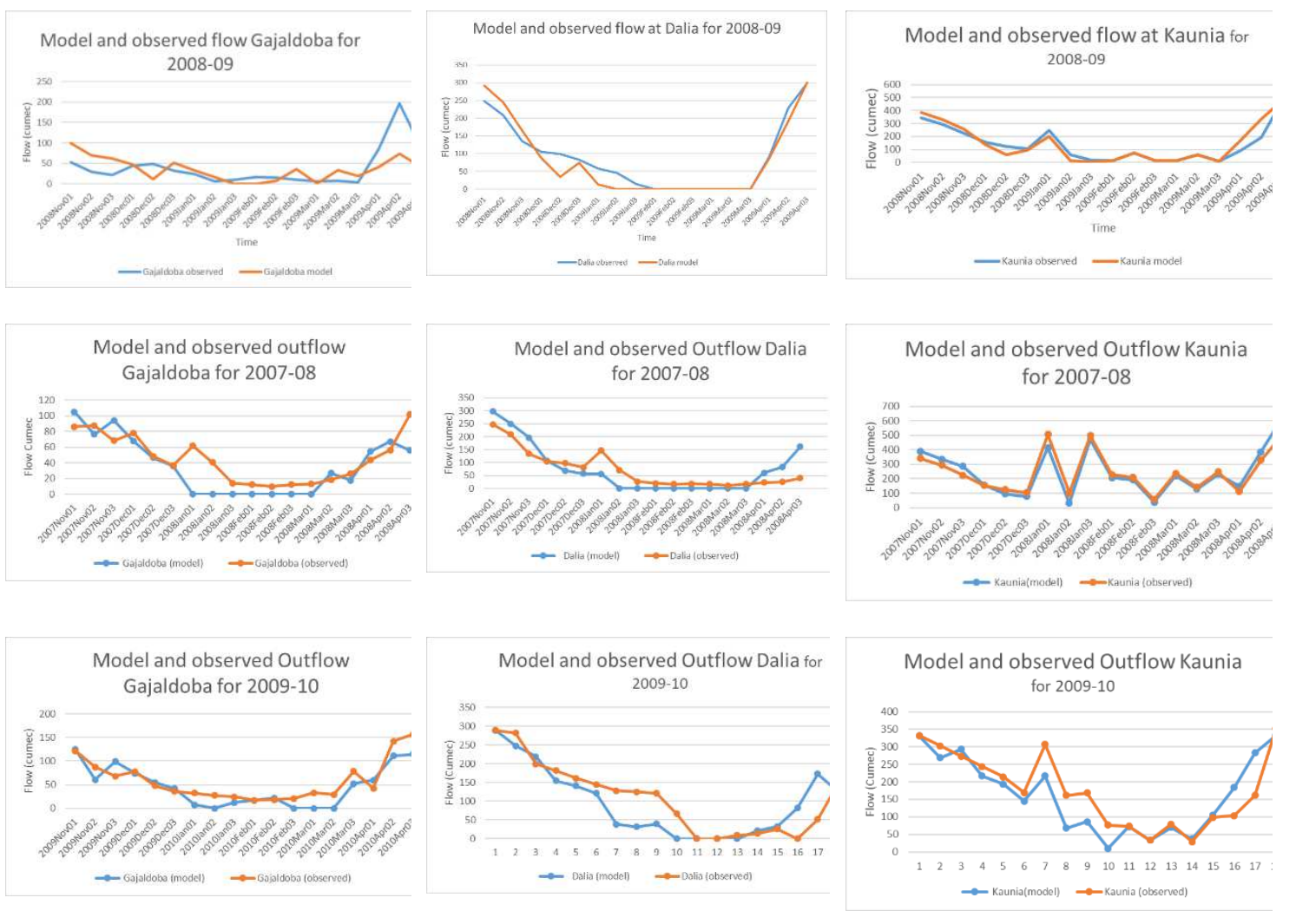

Figure 3 Model outflow vs Observed outflow for 2008-09, 2007-08 and 2009-10

\section{Benefits and trade-offs from water sharing}

Benefits by sector for the base case and water sharing scenarios from a shift to water sharing demonstrate potential gain/loss in each country (Table 4).

Table 4: Total benefits from water use in for both scenario for 2008-09 (dry season)

\begin{tabular}{|c|c|c|c|c|c|c|}
\hline & \multicolumn{6}{|c|}{ Values are in 2019 thousand USD } \\
\hline & \multicolumn{2}{|c|}{$\begin{array}{c}\text { Base Scenario } \\
(2008-09)\end{array}$} & \multicolumn{2}{|c|}{$\begin{array}{c}\text { Water Sharing } \\
\text { Scenario (2008-09) }\end{array}$} & \multirow[t]{2}{*}{$\begin{array}{l}\text { Gain for } \\
\text { India }\end{array}$} & \multirow[t]{2}{*}{$\begin{array}{c}\text { Gain for } \\
\text { BD }\end{array}$} \\
\hline & India & BD & India & BD & & \\
\hline Agriculture & 32,555 & 42,241 & 32,875 & 42,311 & 320 & 70 \\
\hline Hydropower & 5,817 & - & 1,761 & - & 4,056 & - \\
\hline Domestic & 688 & - & 688 & - & - & - \\
\hline Fisheries & 97 & 1,630 & 414 & 1,989 & 317 & 359 \\
\hline Navigation & 29 & 194 & 80 & 234 & 51 & 41 \\
\hline Environment & - & 29,968 & - & 34,078 & - & 4,110 \\
\hline Dredging & 2,385 & 2,970 & 3,889 & 3,833 & 1,504 & 862 \\
\hline Total & 41,571 & 77,003 & 39,707 & 82,445 & $-1,864$ & 5,442 \\
\hline \multicolumn{6}{|c|}{ Basin-wide Gain (if water is shared) } & 3,578 \\
\hline
\end{tabular}


The agricultural benefits vary little between scenarios for both countries with USD 42.2 million in the baseline scenario and USD 42.3 million in the water sharing scenario for Bangladesh, and USD32.6 million realized in India in the baseline scenario compared to USD32.9 million in the water sharing scenario. The small gains are realized because the model allows substitution of groundwater for surface water to supply irrigation. The water sharing scenario reduces diversions for hydro-power, which introduces additional potential for surface water for irrigation. This results in lower cost through less need for expensive groundwater pumping. The domestic benefits in India for municipal use at Shiliguri town doesn't change with a switch to water sharing as domestic water use is restricted to be the highest priority use of diverted water in both scenarios.

Figure 4 provides a visualization of estimated net gain or loss by sector and in total by country for a transition from the base case to the water sharing arrangement with greater flow over the India, Bangladesh border.

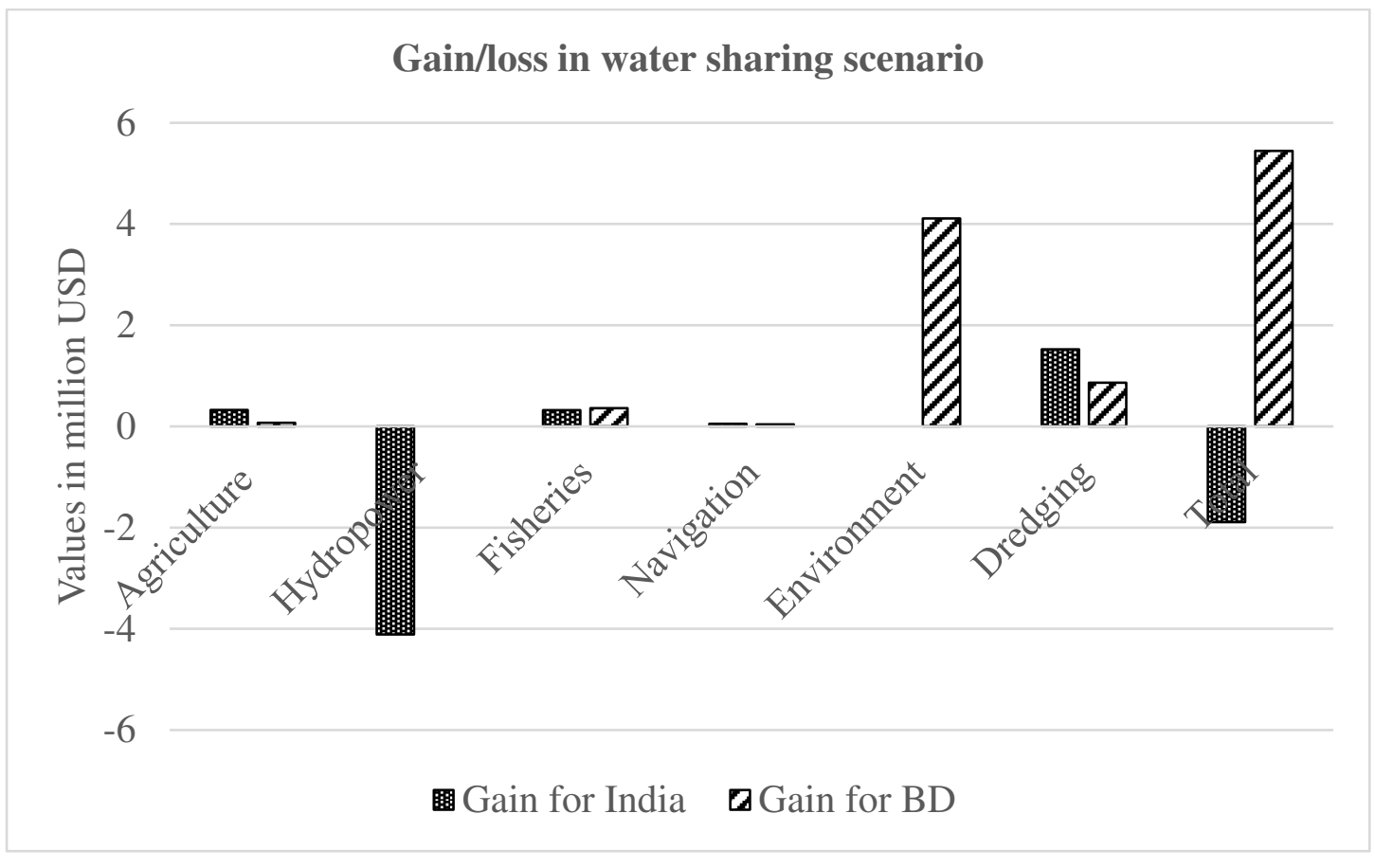

Figure Error! No text of specified style in document.: Gain and loss in different sector for India and BD for 2008-09

The figure shows that the largest loss from the water sharing scenario is a USD 4.056 million loss of hydropower in India, representing a $70 \%$ decline from the baseline value of USD 5.817 million. Figure 4 also shows how total loss in India is less than half of the hydropower loss after considerable gain from reduced dredging and to a lesser extent fishing and navigation benefits in India. This arises because fisheries, navigation, 
dredging, and environment benefits are all produced from instream flows that increase significantly in the water sharing scenario. In average annual terms, fisheries benefits in Bangladesh increase from USD1.630 million to USD1.989 million; navigation benefits for Bangladesh increase from USD194 thousand to USD234 thousand. Fisheries benefits for India are estimated to increase by USD317 thousand while navigation benefits for India are estimated to increase by USD51 thousand.

The estimated growth in dredging benefits in both countries is quite large relative to fishing and navigation benefits: USD 0.863 million for Bangladesh and USD 1.504 million for India. The estimated environmental benefits are by far the largest source of flow (as opposed to extraction) benefit, estimated to be around USD29.968 million and USD34.078 million for baseline and water-sharing scenarios respectively. This is also the category where the largest increase in benefit results from water sharing, a USD 4.110 million dollar increase all in Bangladesh. The total gain from flow related benefits from water sharing (other than hydropower), is estimated at USD 5.372 million for Bangladesh, an $8 \%$ gain. In contrast, the estimated loss of USD 1.872 million for India for a change to the water sharing scenario is equal to $4 \%$ of total Indian baseline benefit from Teestra water.

\subsection{Conclusion}

Our results show that a change from the current water sharing regime, to a regime with more flow across the India, Bangladesh border could produce a net benefit for the basin as whole. However, benefit is uneven across countries and sectors. Both benefit and water use for hydropower decrease in India, though the resulting economic loss is partially offset by benefits to navigation, fisheries, and avoided sediment dredging costs. . For Bangladesh, in contrast, the change in water sharing regime results in benefit for all sectors considered. This suggests that if water is shared as proposed recently, India will lose hydropower but gain fisheries, navigation, and dredging (sediment transport) benefits. On the other hand, Bangladesh will gain in all the sectors including agriculture, fisheries, navigation, dredging, and environmental benefits without any loss in any sector. The inclusion of a broad range of benefits in the modelling shows that India's estimated USD 4 million loss annually would likely be partially offset by gains in most sectors other than hydropower, including: fisheries, navigation, and dredging. As a result, estimated annual total net loss in India of USD 1.9 million (4.5\% of India's current benefit) is less 
than half of the expected net hydropower loss. Potential gains for Bangladesh are estimated at 5.4 million USD, which is $8 \%$ of Bangladesh's present economic benefits from the Teesta - primarily from flow related benefits for environment, navigation and fishing and avoided dredging.

Possible basin-wide net gain is estimated at USD 3.6 million annually, which is $3 \%$ of the estimated value generated with current management. The possibility of a net benefit arises primarily because of high potential for improved instream water values other than hydropower, including fisheries, navigation, dredging and environment. Further, the conclusion of net benefit potential would have been different without the inclusion of the wider set of flow related benefits than is common in HEM practice. This finding leads to the conclusion that benefit estimates for water sharing produced with HEMs are sensitive to scope of water benefits considered. This broadly validates similar conclusions from other HEM evaluation studies that have included wider scopes of flow related benefits (Do et al. 2020; Eamen, Brouwer \& Razavi 2021; Kahil, Dinar \& Albiac 2015; Ringler, Braun \& Rosegrant 2009).

One limitation of this research, arising from data and research effort constraints, is the limited scope of flow related benefits considered. While we model a broader scope than is considered in many HEM studies, we recognize the potential for additional flow related benefits. An important recommendation for future research is continued effort to expand the scope of flow related water benefits included in evaluations of water sharing opportunities. There is clear opportunity to expand consideration of benefits in diverse categories such as: tourism, amenity, micro-climate, soil fertility, groundwater recharge, water quality, thermal power cooling, and water dependent ecosystems benefits, to name a few. Another limitation is that more than just identification of potential for net benefit is required to realize improved net benefit. Another direction for future research, to better support realization of improved transboundary outcomes, is evaluation of more and less cooperative strategies with methods similar to Basheer et al. (2018) in HEMs with broader scope of flow related water benefits.

\section{References}

Abseno, MM 2013, 'Role and relevance of the 1997 UN Watercourses Convention in resolving transboundary water disputes in the Nile', International journal of river basin management, vol. 11, no. 2, pp. 193-203. 
Adhikary, KD, Ahmed, QK, Malla, Sk, Pradhan, BB, Rahman, K, Rangachari, R, Rasheed, KBS \& Verghese, BG 2000, Cooperation on the Eastern Himalayan Rivers Opportunities and Challenges, Konark, Delhi.

Afroz, R \& Rahman, MA 2013, 'Transboundary River water for Ganges and Teesta Rivers in Bangladesh: an assessment', Glob Sci Technol J, vol. 1, no. 1, pp. 100-11.

Amjath-Babu, T, Sharma, B, Brouwer, R, Rasul, G, Wahid, SM, Neupane, N, Bhattarai, U \& Sieber, S 2019, 'Integrated modelling of the impacts of hydropower projects on the waterfood-energy nexus in a transboundary Himalayan river basin', Applied Energy, vol. 239, pp. 494-503.

Bagchi, I 2011, 'Manmohan Singh, Sheikh Hasina put Teesta behind, fix boundary', The Times of India, 7 September 2011, <http://timesofindia.indiatimes.com/india/Manmohan-SinghSheikh-Hasina-put-Teesta-behind-fix-boundary/articleshow/9890426.cms>.

Basheer, M \& Elagib, NA 2018, 'Sensitivity of Water-Energy Nexus to dam operation: A WaterEnergy Productivity concept', Science of the Total Environment, vol. 616, pp. 918-26.

Basheer, M, Wheeler, KG, Ribbe, L, Majdalawi, M, Abdo, G \& Zagona, EA 2018, 'Quantifying and evaluating the impacts of cooperation in transboundary river basins on the Water-EnergyFood nexus: The Blue Nile Basin', Science of the Total Environment, vol. 630, pp. 1309-23.

Bekchanov, M, Ringler, C, Bhaduri, A \& Jeuland, M 2015, 'How would the Rogun Dam affect water and energy scarcity in Central Asia?', Water International, vol. 40, no. 5-6, pp. 856-76.

Bekchanov, M, Sood, A, Pinto, A \& Jeuland, M 2017, 'Systematic Review of Water-Economy Modeling Applications', Journal of Water Resources Planning and Management, vol. 143, no. 8 , pp. 04017037-1-18.

Bekchanov, MB 2014, 'Efficient water allocation and water conservation policy modeling in the Aral Sea Basin'.

Bulk Energy 2019, viewed 30-08-2019, <https://gobulk.com.au/australian-electricity-prices/>.

BWDB 2015, Feasibility of Capital Dredging and Sustainable River Management of Bangladesh, Bangladesh Water Development Board, Dhaka.

De Jager, D, Klessmann, C, Stricker, E, Winkel, T, De Visser, E, Koper, M, Ragwitz, M, Held, A, Resch, G \& Busch, S 2011, 'Financing renewable energy in the European energy market'. 
Department of Irrigation and waterways, G 2017, Teesta Barrage Project, Government of India, Kolkata, viewed 30.04.2017, <https://wbiwd.gov.in/index.php/applications/teesta> .

Digna, RF, Mohamed, Y, van der Zaag, P, Uhlenbrook, S \& Corzo, G 2017, 'Nile River Basin modelling for water resources management-a literature review', International journal of river basin management, vol. 15 , no. 1 , pp. 39-52.

Do, P, Tian, F, Zhu, T, Zohidov, B, Ni, G, Lu, H \& Liu, H 2020, 'Exploring synergies in the waterfood-energy nexus by using an integrated hydro-economic optimization model for the Lancang-Mekong River basin', Science of the Total Environment, p. 137996.

Eamen, L, Brouwer, R \& Razavi, S 2021, 'Integrated modelling to assess the impacts of water stress in a transboundary river basin: Bridging local-scale water resource operations to a river basin economy', Science of the Total Environment, vol. 800, p. 149543.

Eckstein, G \& Sindico, F 2014, 'The Law of Transboundary Aquifers: Many Ways of Going Forward, but Only One Way of Standing Still', Review of European, Comparative \&amp; International Environmental Law, vol. 23, no. 1, pp. 32-42.

Gonzalez, JM, Matrosov, ES, Obuobie, E, Mul, M, Pettinotti, L, Gebrechorkos, SH, Sheffield, J, Bottacin-Busolin, A, Dalton, J \& Smith, DM 2021, 'Quantifying cooperation benefits for new dams in transboundary water systems without formal operating rules', Frontiers in Environmental Science, vol. 9, p. 107.

Grey, D \& Sadoff, C 2003, 'Beyond the river: the benefits of cooperation on international rivers', Water science and technology, vol. 47, no. 6, pp. 91-96.

Habteyes, BG, El-bardisy, HAH, Amer, SA, Schneider, VR \& Ward, FA 2015, 'Mutually beneficial and sustainable management of Ethiopian and Egyptian dams in the Nile Basin', Journal of Hydrology, vol. 529, pp. 1235-46.

Haque, AE, Aich, D, Subhani, R, Bari, E \& Diyan, MAA 2014, Tale of a Tamed River, 34, Asian Center for Development, Sylhet, Bangladesh,

Hossen, MA 2021, 'Transboundary water management dispute resolution through benefit sharing: A case study of the Teesta River between India and Bangladesh', Business School, University of South Australia, Adelaide.

Hossen, MA, Connor, JD \& Faisal, IM 2022, 'Review of Hydro-Economic Models (HEMs) which focus on transboundary river water sharing disputes', Water Policy.

Irena, I 2012, Renewable energy technologies: Cost analysis series. 
Jalilov, S-M, Varis, O \& Keskinen, M 2015, 'Sharing benefits in transboundary rivers: An experimental case study of Central Asian water-energy-agriculture nexus', Water, vol. 7, no. 9, pp. 4778-805.

Jalilov, S-M 2021, 'Emergence of Water-Energy-Food Nexus Resulting from Interbasin Water Transfer: Economic Analysis for a Transboundary River Basin in South Asia', Journal of Water Resources Planning and Management, vol. 147, no. 10, p. 05021016.

Jeuland, M, Wu, X \& Whittington, D 2017, 'Infrastructure development and the economics of cooperation in the Eastern Nile', Water International, vol. 42, no. 2, pp. 121-41.

Kahil, MT, Dinar, A \& Albiac, J 2015, 'Modeling water scarcity and droughts for policy adaptation to climate change in arid and semiarid regions', Journal of Hydrology, vol. 522, pp. 95-109.

Kawser, MA \& Samad, MA 2016, 'Political history of Farakka Barrage and its effects on environment in Bangladesh', Bandung: Journal of the Global South, vol. 3, no. 1, p. 16.

Mianabadi, H, Mostert, E, Pande, S \& van de Giesen, N 2015, 'Weighted bankruptcy rules and transboundary water resources allocation', Water Resources Management, vol. 29, no. 7, pp. 2303-21.

Momblanch, A, Connor, JD, Crossman, ND, Paredes-Arquiola, J \& Andreu, J 2016, 'Using ecosystem services to represent the environment in hydro-economic models', Journal of Hydrology, vol. 538, pp. 293-303.

Mullick, MRA, Babel, MS \& Perret, SR 2010, 'Flow characteristics and environmental flow requirements for the Teesta River, Bangladesh', Proceedings of international conference on environmental aspects of Bangladesh (ICEAB10), Japan, pp. 159-62.

Mullick, MRA, Babel, MS \& Perret, SR 2011, 'Discharge-based economic valuation of irrigation water: Evidence from the Teesta River, Bangladesh', Irrigation and drainage, vol. 60, no. 4, pp. 481-92.

Mullick, MRA, Perret, SR \& Babel, MS 2014, 'Benefit functions for instream water uses - a case of the Teesta River, Bangladesh', Journal of Applied Water Engineering and Research, pp. 1-11.

Nauges, C \& Whittington, D 2009, 'Estimation of water demand in developing countries: An overview', The World Bank Research Observer, vol. 25, no. 2, pp. 263-94.

Ogren, KL 2015, 'Water Governance Process Assessment: Evaluating the Link between Decision Making Processes and Outcomes in the Columbia River Basin', Geography, Oregon State University, Oregon. 
Open Government Data Platform India 2019, viewed 11-01-2019, $<$ httpsdata.gov.incatalogstate-wise-average-rate-electricity-domestic-and-industrialconsumers $>$.

Rai, SP, Wolf, AT, Sharma, N \& Tiwari, H 2017, 'Hydropolitics in transboundary water conflict and cooperation', River System Analysis and Management, Springer, pp. 353-68.

Ringler, C, Braun, Jv \& Rosegrant, MW 2009, 'Water policy analysis for the Mekong River Basin', Water International, vol. 29, no. 1, pp. 30-42.

Sadoff, CW \& Grey, D 2005, 'Cooperation on international rivers: A continuum for securing and sharing benefits', Water International, vol. 30, no. 4, pp. 420-27.

Sarkar, DSK 2017, 'Sharing the Teesta', The Statesman, 4 April 2017, $<$ http://www.teriin.org/index.php?option=com featurearticle\&task=details\&sid=1064\&ltemid $=157 \& \mathrm{f}=1 \&$ utm source=apr17newsletter $>$.

Shiliguri Subdivision 2019, viewed 28-10-2019, <http://www.siliguri.gov.in/about.html>.

Srinivasan, V, Gorelick, SM \& Goulder, L 2010, 'Sustainable urban water supply in south India: Desalination, efficiency improvement, or rainwater harvesting?', Water Resources Research, vol. 46 , no. 10.

Stefano, LD, Svendsen, M, Giordano, M, Steel, BS, Brown, B \& Wolf, AT 2014, 'Water governance benchmarking: concepts and approach framework as applied to Middle East and North Africa countries', Water Policy, vol. 16, no. 6, pp. 1121-39.

Strzepek, KM, Yohe, GW, Tol, RS \& Rosegrant, MW 2008, 'The value of the high Aswan Dam to the Egyptian economy', Ecological Economics, vol. 66, no. 1, pp. 117-26.

The Asia Foundation 2013, Political Economy Analysis of the Teesta River Basin, The Asia Foundation, New Delhi.

Tilmant, A \& Kinzelbach, W 2012, 'The cost of noncooperation in international river basins', Water Resources Research, vol. 48, no. 1.

Vinca, A, Parkinson, S, Riahi, K, Byers, E, Siddiqi, A, Muhammad, A, llyas, A, Yogeswaran, N, Willaarts, B, Magnuszewski, P, Awais, M, Rowe, A \& Djilali, N 2021, 'Transboundary cooperation a potential route to sustainable development in the Indus basin', Nature Sustainability, vol. 4, 04/01, pp. 1-9. 
Whittington, D, Wu, X \& Sadoff, C 2005, 'Water resources management in the Nile basin: the economic value of cooperation', Water Policy, vol. 7, no. 3, pp. 227-52.

Wu, X, Jeuland, M, Sadoff, C \& Whittington, D 2013, 'Interdependence in water resource development in the Ganges: an economic analysis', Water Policy, vol. 15, no. S1, pp. 89-108.

Yorth, B 2014, 'International Mekong River basin: events, conflicts or cooperation, and policy implications'. 